\title{
The Type of Sport Celebrity Transgression: Does it Impact on the Associated Sponsors and Sport?
}

\author{
Anne-Marie Sassenberg
}

The brand image transfer and associative learning theories indicate the transference of the positive sport celebrity brand image to the sponsor brand image during sponsorship (McCracken 1989). Furthermore, studies show that the characteristic of sport celebrity transgressions (off-field and on-field) impact on consumers' perceptions of transgressions (Summers et al. 2008). However, the potential transfer of a negative sport celebrity brand image on the associated sponsors and sport, in relation to the characteristics of the sport celebrity transgression (SCT), has largely been ignored. This paper investigated how the off-field and on-field SCT impact on the brand image of the celebrity's associated sponsors and sport. The study investigated nine different transgression scenarios and analyzed $2 \quad 987$ online comments. The findings indicated that the characteristics of SCTs can further be categorized into more specific groups.

Dr. Anne-Marie Sassenberg

University of Southern Queensland

Brisbane, Australia

Keywords-communication, celebrity sponsorship, brand image, transgressions.
Acknowledgements: The author wants to acknowledge Professor Marie Kavanagh, Associate Professor Jane Summers and Associate Professor Melissa Johnson Morgan for their contribution to the research process.

Sponsorship is previously described as an investment in an activity, person, or event (sponsee), for access to the commercial potential associated with the activity, person or event by the sponsor (1). The International Events Group defines sponsorship as a cash and/or in-kind fee paid to a property in return for access to the exploitable commercial potential associated with the property (2). These definitions highlight the importance of association between the sport celebrity brand image and the sponsor brand image, during sponsorship.

Since celebrity sponsorship is also referred to as a brand alliance (3), the sport celebrity brand image has the potential to impact on the brand image of the other brands in the alliance, through association-when SCTs occurs. Previous research shows that whether the SCT is characterized as off field or on field may impact on consumers' perceptions of the transgression effects $(4,5,6)$. On-field SCTs will be defined, for the purpose of this study, as any immoral, illegal or anti-social act of behavior undertaken by a sport celebrity that relates to the sport the celebrity participates in. According to sport managers, on-field SCTs are easier to handle and manage (5), but are still regarded as having a potential negative impact on sponsors and sport $(7,5)$.

Despite the increased focus on celebrity sponsorship (8), few studies have attempted to address the possible negative effect of the different characteristics of SCTs. Several studies consider the literature of negative brand image transfer by highlighting the negative impact on the image of the sport celebrity's associated sponsors and sport $(5,7,9,10)$, but fail to show which 
characteristic is responsible for the change in consumer attitudes.

Because the main aim of sponsorship is to seek improvement in consumers' response towards a brand (1), it is important to include consumers' perceptions when investigating the effects of SCTs. Therefore, this paper examines the relationships between consumer attitudes towards the brand image of the celebrity's associated sponsors and sport, following different characteristics of SCTs. A discussion on sponsorship mechanism that explains attitude change is first provided, followed by the verification of the relationships through online media data collection. Lastly, the findings are presented.

\section{Literature Review.}

Brand image transfer and balance theory are the mechanisms responsible for attitude change in sponsorship (11).

\section{Brand image transfer theory}

Brand image transfer theory explains the transfer of positive brand images between the endorsed sponsee and the sponsor $(10,12,13)$ this correlates with another study's (14) conceptualization of the sources of brand associations, which is explained in terms of associative learning theory.

The associative learning theory indicates the connectivity between the sponsee brand image and the sponsor brand image $(14,15)$. Therefore, it is possible that, during sport celebrity sponsorship, the sport celebrity brand image, the associated sponsor brand image, and the associated sport brand image, represent different nodes in the minds of the consumer. This connectivity between the associated brands ensure the spreading of information (15). It is, thus, possible that when an SCT impacts on the sport celebrity brand image, the SCT may have an accompanied attitude change towards the brand image of the celebrity's associated sport and sponsors.

\section{Balance theory}

Several scholars investigate attitude change through balance theory $(16,17,18)$. Balance theory states that consumers perceive elements in their environment as appearing in groups of three, in a triangular relationship among the three elements (20). In this triangular relationshipconsumers value harmony and balance between the three elements in the relationship (21).

The consumer seeks a balance in relationships by adjusting the evaluation of the celebrity, or by reconsidering the attitude towards the sponsor (16). However, when the SCT has the ability to change consumers' attitudes towards one entity in the triad (such as the sport celebrity brand image), the attitudes in the triad can be further affected in order to seek balance relationships. The brand image transfer and balance theory indicate that when one brand transgressed, it can have an accompanied negative impact on the associated brands. However, no study that we are aware of has investigated the impact of the characteristics of an SCT on the other brands in the triad of relationships. Therefore, this paper suggests the following research questions:

RQ1: What is the impact of the characteristics of an SCT on the brand image of the celebrity's associated sponsors?

RQ2: What is the impact of the characteristics of an SCT on the brand image of the celebrity's associated sport?

\section{Methods}

Online media data collection was conducted to investigate this study's research questions. This method was a convenient and cost effective method of research $(22,23)$ that further ensured broad connectivity and high accessibility (23). Online media data collection also experiences some disadvantages, such as the possibilities of multiple submissions; subject anonymity and data security $(24,23)$. In order to overcome his problem, this study discarded data of subjects that offered more than one comment. Subject anonymity and data security were not regarded as major disadvantages in this study, because subjects rarely identified themselves. In some instances, when names were used on the discussion boards, it was not included in the study.

The data collection processed consisted of the following six steps: 1) the selection of various SCTs; 2) the selection of online sites; 3 ) developing a contact summary sheet to capture the online media data; 4) testing the contact summary sheet; 5) uploading contact summary sheets on the NVivo software, and 6) recording of all sites used. 
The selection of various SCTs were based on: choosing real on-field SCT scenarios; SCTs that included different characteristics, and availability of consumers' comments on online media. Since online media sites were selected on search engines such as Google, the SCT scenarios depended on consumers' responses to online media.

In order to ensure the contact summary sheet was correct, and to confirm the themes developed for this study, the first case was manually analyzed. Following the manual analysis, the uploading of all contact summary sheets on NVivo software took place. NVivo analysis is a Qualitative Data Analysis Software (QDAS) and is widely used in social science research to facilitate the analysis of qualitative data (25).

In order to analyze, arrange, summarize and present the nominal data (26), each theme categorized according to the impact on the celebrity's associated sport and the impact on the associated sponsors. Evidence of transparency and consistency were accomplished in this study with the use of a pre-designed contact summary sheet to record all steps and dates followed in this study; and to summarize the lists of websites used. This consistency and transparency of data management helped to address the validity in the research program (27).

\section{Findings}

The findings are presented according to the impact of SCTs on the sport celebrity's associated sponsors brand image, followed by the impact on the sport brand image.

Impact on the Associated Sponsor Brand Image Table 1 indicates the impact of SCTs on the sport celebrity's associated sponsor brand image.

Table 1: Impact of the Characteristics of SCTs on the Sport Celebrity's Associated Sponsor Brand Image

\begin{tabular}{|l|c|c|c|}
\hline $\begin{array}{l}\text { SCT } \\
\text { Characteristic }\end{array}$ & $\begin{array}{l}\text { No. of } \\
\text { positive } \\
\text { comments }\end{array}$ & $\begin{array}{l}\text { No. of } \\
\text { negative } \\
\text { comments }\end{array}$ & Total \\
\hline Off-field SCTs & 15 & 15 & 30 \\
\hline On-field SCTs & 0 & 0 & 0 \\
\hline Total & $\mathbf{1 5}$ & $\mathbf{1 5}$ & $\mathbf{3 0}$ \\
\hline
\end{tabular}

From a total of 30 comments, related to the impact of SCTs on the sport celebrity's associated sponsor brand image, 15 comments were negative and 15 comments were positive. Table 1 shows the off-field SCTs were the only SCTs to have a negative impact on the celebrity's associated sponsor brand image.

When off-field SCTs occurred, consumer attitudes varied. There was a group of customers that indicated a negative attitude towards the sport celebrity's associated sponsor brand image, when off-field SCTs occurred. For example:

"I for one am glad that people started to boycott Kellogg's for dropping him."

Another consumer indicated that they will change their behavior because of the off-field SCT. For example:

Don't buy Nike or Wilson. We as normal average everyday people need to take a stand toward this horrifying behavior."

A consumer supporting the behavior changes indicating:

$$
\text { "p.s. just threw away my Gillette razor." }
$$

The findings, furthermore, indicated the same amount of positive consumer attitudes towards the sponsor brand image. Consumer indicated as follows:

"These sponsors are short-sighted, within a short period of time, this will all blow over and he will be back winning championships...then he will be laug\$\$\$hing."

Based on these findings, this study suggests that on-field SCTs may not necessarily have a negative impact on the sport celebrity's associated sponsor brand image, while off-field SCTs may have a negative impact on the sport celebrity's associated sponsor brand image.

\section{Impact on the Associated Sport Brand Image}

Table 2 indicates the impact of the characteristics of SCTs on the sport celebrity's associated sport brand image. 
Table 2: Impact of the Characteristic of SCTs on the brand image of the associated sport

\begin{tabular}{|l|c|c|c|}
\hline $\begin{array}{l}\text { SCT } \\
\text { Characteris } \\
\text { tics }\end{array}$ & $\begin{array}{l}\text { No. of } \\
\text { positive } \\
\text { comments }\end{array}$ & $\begin{array}{l}\text { No. of } \\
\text { negative } \\
\text { comments }\end{array}$ & Total \\
\hline Off-field & 7 & 82 & 89 \\
\hline On-field & 25 & 24 & 49 \\
\hline Total & $\mathbf{3 2}$ & $\mathbf{1 0 6}$ & $\mathbf{1 3 8}$ \\
\hline
\end{tabular}

From a total of 138 comments related to the impact of SCTs on the brand image of the associated sport, 106 comments were negative, and 32 comments were positive. Overall, the brand image of the associated sport was perceived as negative when an off-field SCT occurred, while more positive when an on-field SCT followed.

When on-field SCTs occurred, consumers indicated an overwhelmingly high number of positive comments. Consumers indicated they enjoy the SCT, for example:

"Mate it's a brutal, physical game. It's

blokes like you that try to soften the game,

which nobody else wants."

Another consumer suggested that the SCTs related and enjoyed more to men. For example:

"Rugby League is a game played by men.

When the two best teams in the comp get together and produce the game of the season, the NRL lead by Gallop and other net ball supporters get upset when the tension spills over into a bit of biff."

Furthermore, some consumer perceived the sport brand image as negative when on-field SCTs happened. For example:

Doping is a huge problem in cycling, but the assertion that a Tour stage (or even a complete Tour) is physically impossible without drugs is flat-out wrong.

Another consumer also perceived the sport as negative when on-field SCTs occurred. For example:

Cycling needs to be removed from all sports websites. Yes, I know, most sports have their issues with PEDs, but not nearly in the scale as cycling.
When off-field SCTs occurred consumers indicated a negative attitude towards the sport celebrity's sport brand image. For example:

Which goes to the main problem at West

Coast - just like Hawthorn, there appears

to be a serious drug abuse culture at this club (Ben Cousins)

Consumers seemed to perceive the sport brand image as negative, because of the previous offfield SCTs incidents. For example:

"The culture of girl groupies and these drunk footy players has been with the NRL for many many years."

A consumer linked the role model ability of the sport celebrity brand image with the impact on the sport brand image. For example:

"He is a bad role model and now the NRL need to clean up their act so we aren't subjected to these stories again! Other sports have great role models and you never hear of this stuff happening."

Based on these findings, this study suggests that off-field SCTs have an overwhelmingly negative impact on the sport celebrity's associated sport brand image, while on-field SCTs have a more positive impact on the sport celebrity's associated sport brand image.

\section{References}

(1) D.Z. Basil and P.M. Herr, "Attitudinal balance and caused related marketing: An empirical application of balance theory", Journal of Consumer Psychology, 16, vol. 4, 2006, pp. 391-403.

(2) M.H. Birnbaum, "Human Research and Data Collection via the Internet", Annual Review Psychology, vol.55, 2004, pp. 803-832. J. Crimmins, and M. Horn, "Sponsorship: From management ego trip to marketing success", Journal of Advertising Research, vol. July/August, 1996, pp. 11-21.

A. Dean and J. Sharp, "Getting the most from NUD*IST/NVivo", The Electronic Journal of Business Research, available online at www.ejbrm.com, 4, vol. 1, 2006, pp. 11-22. D.H. Dean, "Brand endorsement, popularity, and event sponsorship as advertising cues affecting consumer pre-purchase attitudes", Journal of Advertising, 28, vol. 3, 1999, pp. 1-12. D.H. Dean, "Associating the corporation with a charitable event through sponsorship", Journal of Advertising, 31, vol. 4, 2002, pp. 77-87.
N.K. Denzin and Y. Lincoln Y., "Handbook of qualitative research', Thousand Oaks California: Sage Publications, 1994. 
(10) E. Gummeson, "Qualitative research in Marketing: road map for a wilderness of complexity and unpredictability", European Journal of Marketing, 39, vol. 3/4, 2005, pp. 309-327.

(11) K.P. Gwinner, B.V. Larson and S.R. Swanson, "Image transfer in coporate event sponsorship: Assessing the impact of team identification and event-sponsor fit", International Journal of Management \& Marketing Research, 2, vol. 1, 2009, pp. 1-15.

(12) E. Halonen-Knight and L. Hurmerinta, "Who endorses whom? Meanings transfer in celebrity endorsement", Journal of Product \& Brand Management, 19, vol.6, 2010, pp. 452-460.

(13) F. Heider, "The psychology of interpersonal relations", New York: John Wiley \& Sons, 1958.

(14) J.R. Henseler, B. Wilson and D. De Vreede, "Can sponsorships be harmful for events? Investigating the transfer of associations from sponsors to events", International journal of sports marketing \& sponsorship, 10, vol. 3, 2009, pp. 244-251.

(15) K.L. Keller, "Conceptualizing, measuring, and managing customer-based brand equity", Jounal of Marketing 57, vol. Jan, 1993, pp. 1-22.

(16) G. McCracken, "Who is the celebrity endorser? Cultural foundations of the endorsement process", Journal of Consumer Research, 16, vol. December, 1989, pp. 310-321.

(17) T. Meenaghan, "Sponsorship and advertising: A comparison of consumer perceptions",

Pscychology \& Marketing, 18, vol. 2, 2001, pp. 191-215.

(18) F.M. Miller and G.R. Laczniak, "The ethics of celebrity-athlete endorsement: What happens when a star steps out of bounds?" Journal of Advertising Research, vol. September, 2011, pp. 499-510.

(19) F. Mungeam, "Commenting on the news: How the degree of anonymity affects flaming online. Communication and Leadership studies", Gozaga Univeristy, Washington, vol. December, 2011, pp. 19-21.

(20) R. Ohanian, "Construction and Validation of a Scale to Measure Celebrity Endorsers' Perceived Expertise, Trustworthiness, and Attractiveness", Journal of Advertising, 19, vol. 3, 1990, pp. 39-52.

(21) J.W. Pracejus, G.D. Olsen and N. Brown, "On the prevalence and impact of vague quantifiers in the adverrtising of cause-related marketing (CRM)", Journal of Advertising, 32, vol. 4, 2004, pp. 19-28.

(22) U.D. Reipts, "The Web experimental psychology lab: five years of data collection on the Internet". Behav. Res. Methods Instrum. Comput., vol. 33, 2001, pp. 201-211.

(23) N.J. Rifon, S.M. Choi, C.S. Trimble and H. Li, "Congruence effects in sponsorship: the mediating role of sponsor credibility and consumer attributions of sponsor motive", Journal of Advertising, 33, vol. 1, 2004, pp. 29-42.

(24) E.A. Selvanathan, S. Selvanathan and G. Keller, "Business Statistics, Abridged: Australia and New Zealand" (Vol. 6th edition). Australia: Cengage Learning, 2014.

(25) M.A. Smith and B. Leigh, "Virtual subjects: Using the Internet as an alternative source of subjects and research environment. Behaviour Research Methods", Instruments \& Computers, 29, vol. 4, 1997, pp. 496-505.

(26) H.A. Solberg, D.V. Hanstad and T.A. Thoring, "Doping in elite sport - do the fans care? Public opinion on the consequences of doping scandals", International journal of sports marketing \& sponsorship, vol. April, 2010, pp. 185-119.

(27) J. Summers and M. Johnson Morgan, "More than just the media: Considering the role of public relations in the creation of sporting celebrity and the management of fan expectations", Public Relations Review, vol. 34, 2008, pp. 176-182. K. Westberg, C. Stavros and B. Wilson, "An examination of the impact of player transgressions on sponsorship b2b relationships", International journal of sports marketing \& sponsorship, vol. January, 2008, pp. 125-134.

(29) D.W. White, L. Goddard and N. Wilbur, "The effects of negative information transference in the celebrity endorsement relationship", International Journal of retail \& distribution management, 37, vol. 4, 2009, pp. 322-334.

(30) B. Wilson, C. Stavros and K. Westberg, "Player transgressions and the management of the sport sponsor relationship", Public Relations Review, vol. 34, 2008, pp. 99-107.

Anne-Marie Sassenberg is a Marketing lecturer at the University of Southern Queensland. Her area of interest is Sport Marketing, Branding, Sport Celebrity Brand Image, Transgressions, Scandals, Consumer Behavior and Marketing Communication. Her areas of teaching is Marketing Communication, Marketing Channels, Consumer Behavior and Marketing Strategy. 